\author{
Kornelia CzerwińsKa
}

Akademia Pedagogiki Specjalnej w Warszawie

\title{
REFLEKSYJNOŚĆ W PRACY DYDAKTYCZNEJ Z UCZNIEM Z NIEPEŁNOSPRAWNOŚCIĄ WZROKU - WYBRANE ASPEKTY TEORETYCZNE
}

\begin{abstract}
Streszczenie: W modelowej sylwetce pedagoga specjalnego opisywanej w tekstach pedeutologicznych na naczelnym miejscu - obok sprawności i umiejętności kształtowanych na bazie wiedzy ogólnoteoretycznej i metodycznej - znalazła się taka cecha, jak refleksyjność. Umiejętność przyjęcia krytycznej postawy wobec własnego myślenia i działania jest szczególnie istotna w pracy dydaktycznej z uczniami o odmiennym sposobie percepcji. Refleksyjność czyni nauczyciela bardziej otwartym i wrażliwym na swoiste dla tych uczniów metody poznawania rzeczywistości materialno-przyrodniczej i kulturowo-społecznej, tym samym przyczynia się do uniknięcia niewłaściwych praktyk wychowawczych i pedagogicznych. Efektywność działań tyflopedagoga nie jest determinowana wyłącznie przez umiejętność zastosowania wiedzy teoretycznej w praktyce, lecz przez zdolność do refleksji nad aktualnie realizowanymi i już zakończonymi czynnościami. Refleksja nauczyciela nad własnym działaniem odgrywa ważną rolę zarówno na etapie diagnozy specjalnych potrzeb edukacyjnych ucznia z niepełnosprawnością wzroku, jak i w trakcie planowania, realizacji i ewaluacji zajęć dydaktycznych. Nauczyciel musi stale gromadzić materiał obserwacyjny z różnych sytuacji szkolnych i dokonywać analizy dynamicznych interakcji zachodzących między projektowanym przez niego środowiskiem uczenia się a aktualnymi możliwościami i potrzebami danego ucznia z niepełnosprawnością wzroku. Tyflopedagog powinien być otwarty na częste zmiany zachodzące w analizowanym obszarze.
\end{abstract}

Słowa kluczowe: refleksyjność, nauczyciel, tyflopedagog, niepełnosprawność wzroku 


\section{WPROWADZENIE}

Stale zmieniająca się rzeczywistość społeczno-kulturowa i polityczno-gospodarcza generuje potrzebę przyjmowania postawy refleksyjnej zarówno wobec następujących w społeczeństwie przemian i ich konsekwencji, jak i własnych działań (Kojs 2012). Pogłębiony namysł nad istotą i następstwami aktualnie obserwowanych trendów społecznych jest niezbędny do świadomego podejmowania wyborów o charakterze adaptacyjnym lub emancypacyjnym, prowadzącego do autorskiej kreacji ścieżki swojego życia. We współczesnej edukacji silnie akcentuje się więc znaczenie zdolności do krytycznego myślenia, umiejętności dostrzegania i trafnego definiowania problemów, biegłości w wykorzystywaniu i przetwarzaniu informacji płynących z różnych źródeł, kreatywności ujawniającej się w podejmowanej aktywności (Perkowska-Klejman 2013). Rozwój tych kompetencji u uczniów uznawany jest za jeden z podstawowych celów systemu kształcenia w społeczeństwie wiedzy. Kształtowanie u uczniów postawy refleksyjnej wymaga odpowiednich oddziaływań ze strony nauczyciela, który - odchodząc od prostego przekazu gotowych pakietów informacji przeznaczonych do mechanicznego zapamiętania - stwarza uczniom okazję do samodzielnego gromadzenia doświadczeń, wskazuje na złożoność i niejednoznaczność poznawanych zagadnień, zachęca do analizy i oceny zjawisk z różnych perspektyw, inspiruje do podejmowania prób samodzielnej interpretacji rzeczywistości i krytycznego oglądu doświadczenia. Taki sposób organizacji procesu uczenia się-nauczania jest możliwy wówczas, gdy „podstawą profesjonalnego rozwoju pedagoga jest krytyczna refleksja i zgłębianie kontekstów własnego działania” (Nowicka 2006, s. 517).

\section{REFLEKSYJNOŚĆ - KONCEPTUALIZACJA POJĘCIA}

Refleksyjność to pojęcie złożone, nieco odmiennie ujmowane i definiowane $\mathrm{w}$ aspekcie filozoficznym, teologicznym i pedagogicznym. Od zawsze termin ten był łączony z mądrością, dojrzałością, świadomością. Bliskie znaczeniowo są mu takie określenia, jak kontemplacja, czyli rozważanie, rozpamiętywanie, przypatrywanie się czemuś w skupieniu, oraz medytacja rozumiana jako zagłębianie się w myślach, poświęcanie czasu na rozmyślania. W szerokim ujęciu refleksyjność to „wszelka aktywność intelektualna (epistemiczna), a także - w niektórych koncepcjach - związana z nią aktywność motywacyjno-emocjonalna (uwzględniająca pragnienia, cele, intencje), która zmierza do poznania czegoś: przedmiotu zewnętrznego lub własnej aktywności świadomościowej, czyli wszystkiego, co znajdzie się w polu ludzkiej świadomości” (Słaba 2014, s. 322). Istotną kwestią staje się tu poziom dokonywanych przez osobę analiz myślowych. Cytowana autorka zauważa, że do 
prawdziwej refleksji konieczny jest głębszy namysł, wnikliwe rozważanie i analizowanie dowolnie wybranego zjawiska.

Wymóg pogłębienia rozmyślań, aktywnego i dokładnego rozpatrywania danej kwestii sygnalizowany jest także w publikacjach z dziedziny pedagogiki poświęconych refleksyjności, przy czym wskazuje się w nich przede wszystkim na nowe, nieprzewidywalne, słabo dookreślone i/lub złożone sytuacje problemowe jako główne źródło uaktywniające myślenie refleksyjne. Niepewność pojawiająca się w warunkach braku jednoznacznego rozwiązania problemu skłania do refleksyjności, czyli analizowania - na podstawie posiadanych wiadomości oraz opinii i postaw wyrażonych przez innych - możliwej postaci wiedzy w odniesieniu do przyczyn, które uzasadniają przyszłe konkluzje płynące z podjętego myślenia. Zdaniem Carol Rodgers (2002, za: Perkowska-Klejman 2013) przechodzenie od jednego do drugiego doświadczenia powoduje sukcesywne wzrastanie samowiedzy człowieka. Refleksyjne myślenie, które cechuje systematyczność, rygoryzm i zdyscyplinowanie typowe dla analiz naukowych, ma charakter społeczny, czyli odbywa się w interakcji z innymi. Refleksyjności sprzyja postawa, w której rozwój intelektualny własny oraz innych osób jest uznawany za cenną wartość.

W ujęciu pedagogicznym ważny jest fakt, że refleksyjność prowadzi do samopoznania i rozwoju zdolności do dialogowego sposobu bycia (bycie w dialogu z samym sobą i innymi), tym samym pełni podstawową funkcję w procesie samowychowania (Chudy 2006). Kwestię tę akcentuje Teresa Hejnicka-Bezwińska (2008, s. 502), definiując refleksyjność jako „zdolność do analizowania uzyskanych doświadczeń oraz włączania nowych danych, informacji, wiedzy do posiadanych struktur poznawczych i tworzenia nowych powiązań wiedzy z działaniem”. Refleksja łączy się ściśle z samokontrolą, dotyczy bowiem tego wymiaru samoświadomości, w którym odbywa się proces porównywania różnych decyzji, działań i ich skutków oraz szacowania wartości następstw dokonanych lub antycypowanych wyborów. W przestrzeni edukacyjnej podmioty odznaczające się refleksyjnością stale dokonują samooceny zarówno przez obserwację zachowań osób, z którymi wchodzą w dynamiczne interakcje, jak i przez wgląd we własne postępowanie (analiza myślowa przed działaniem, w trakcie i po zakończeniu). Regularnie wyznaczają sobie kolejne cele oraz wykazują optymizm i wytrwałość w dążeniu do ich osiągnięcia, przejawiając przy tym zdolność do wykorzystywania posiadanej i aktualnie zdobywanej wiedzy oraz doświadczenia praktycznego w celu modyfikowania swojego zachowania. Refleksja pozwala im na trafną ocenę zakresu wiedzy, którą dysponują, poziomu umiejętności, rodzaju uzdolnień oraz podejmowanie działań zmierzających do rozwoju tych kompetencji, co umożliwia sprostanie wyższym standardom (Paris, Ayres 1997). W przypadku uczniów oddziałuje to pozytywnie na umiejętność organizacji procesu uczenia się, zaś w szerszej perspektywie - na planowanie ścieżki 
edukacyjnej i dokonywanie trafnych wyborów edukacyjno-zawodowych. Z kolei u nauczycieli wpływa na doskonalenie warsztatu zawodowego, stając się jednym z zasadniczych elementów stylu pracy. W obu tych grupach kompetencje refleksyjne w znacznym stopniu decydują o ogólnym rozwoju osobowościowym, w tym także etyczno-moralnym, gdyż skłonność do pogłębionego namysłu nad własnym działaniem oraz istotą poszczególnych elementów doświadczanej rzeczywistości ułatwia dokonywanie zmiany dotychczasowych przyzwyczajeń, pozwala na uwolnienie się od różnego typu deformacji poznawczych, zwiększa otwartość na odmienność przyjmowanych perspektyw i poglądów, uczy odpowiedzialności, ukierunkowuje uwagę na świat wartości. Jak podkreśla Wojciech Chudy (2006, s. 72):

[...] stopień refleksyjności danej jednostki ludzkiej decyduje często o jej sprawności intelektualnej i o morale. Ważne dla pedagogiki jest to, że to sama jednostka osobowa poznaje i rozstrzyga o ukierunkowaniu swojego działania w ujęciu aksjologicznym i etycznym, to zaś stanowi centralny element samowychowania.

\section{REFLEKSYJNOŚĆ W PRACY NAUCZYCIELA}

Poszukiwania nowych rozwiązań w zakresie standardów jakości kształcenia oraz funkcji i kompetencji nauczycieli, wynikające przede wszystkim z dynamicznych przemian życia społecznego (Rynio 2009), wyraźnie zmierzają w kierunku modelu pedagoga będącego refleksyjnym profesjonalistą. Wśród licznych kwalifikacji i kompetencji oczekuje się od nauczycieli na każdym etapie kształcenia przygotowania teoretycznego i praktycznego do zaspokajania wielostronnych potrzeb rozwojowych uczniów zdolności do twórczej inicjatywy, umiejętności elastycznego dostosowywania swoich działań do zmieniających się warunków, efektywnego funkcjonowania w sytuacjach nowych, w których rutynowe procedury okazują się niewystarczające. Za niezbędną uznaje się ciągłą pracę nad rozwojem takich zasobów osobowych, jak: kreatywność, odpowiedzialność, zdyscyplinowanie, opanowanie (Minczanowska, Hruzd-Matuszczyk 2013).

Refleksję pedagogiczną postrzega się jako istotny element warsztatu pracy pedagoga. Wynika ona z twórczego podejścia nauczyciela do rozwiązywania zadań dydaktyczno-wychowawczych, jednocześnie staje się inspiracją i źródłem innowacji pedagogicznych (Śliwerski 2010). Do działań typowych dla refleksyjnych nauczycieli, propagujących w procesie nauczania myślenie krytyczne, Iwona Czaja-Chudyba (2008) zalicza m.in.:

- stałe analizowanie własnych procesów myślenia i praktycznego działania oraz dążenie do zrozumienia i interpretacji motywów własnych działań w procesie dydaktycznym; 
- tworzenie sytuacji dydaktycznych zachęcających uczniów do samodzielnego rozwiązywania problemów i krytycznej analizy, a także dokonywania wyboru konkretnych aktywności z dostępnego repertuaru działań;

- zmienianie opinii pod wpływem wiarygodnych argumentów, uznawanie popełnianych przez siebie błędów;

- $\quad$ wykazywanie ciekawości poznawczej i dążenie do ustawicznego uczenia się;

- konstruowanie sytuacji dydaktycznych w taki sposób, aby wyznaczone cele nauczania zostały osiągnięte, a uczniowie przejawiali autonomiczną motywację;

- poszukiwanie innowacyjnych, skutecznych i etycznych rozwiązań sytuacji problemowych;

- wykazywanie wrażliwości na uczucia i kompetencje innych;

- włączanie uczniów w proces tworzenia zasad obowiązujących w procesie kształcenia, w tym w systemie kontroli wiedzy.

Refleksja jest aktywizowana przez krytyczne myślenie, które pozwala nauczycielowi w pełni zrozumieć społeczne, ideologiczne i praktyczne zakorzenienia, powiązania i odniesienia przekazywanych wiadomości (Czaja-Chudyba 2013). Myślenie krytyczne jako cecha i narzędzie nauczyciela stanowi centralną kategorię w koncepcji zdarzeń krytycznych Davida Trippa, która pozwala na identyfikację motywów, przyczyn, zachowań uczniów w danej sytuacji, umożliwiając odkrycie przez pedagoga znaczenia danego zdarzenia, zarówno w wymiarze bezpośrednim, jak i w bardziej ogólnym kontekście. Analiza zdarzenia z codziennej praktyki, które zostało uznane przez nauczyciela za krytyczne ze względu na ujawniany przez nie problem czy strukturę, może mieć charakter praktyczny, diagnostyczny, refleksyjny lub krytyczny. W pierwszym przypadku analiza koncentruje się głównie na przebiegu zdarzenia i dąży do podjęcia konkretnych działań (co, jak, kiedy, gdzie powinienem zrobić?). Diagnostyczny typ analizy pozwala zgromadzić szczegółowe informacje o danej sytuacji (co się zdarzyło? co było przyczyną? jakie są skutki? co ta sytuacja oznacza? dlaczego ta sytuacja miała miejsce?), dzięki czemu możliwe staje się odkrycie jej mechanizmu oraz wielowymiarowych następstw. Analiza refleksyjna dotyczy uczuć doświadczanych przez uczestników zdarzenia oraz oceny znaczenia sytuacji (czy to podoba się mnie/innym? czy to jest dobre? dlaczego?). Analiza o charakterze krytycznym skupia się na kwalifikacji danej sytuacji do określonej kategorii oraz ocenie społecznej (przykładem? czego jest to zdarzenie? czy to jest sprawiedliwe?). Dzięki stosowaniu tego typu analizy nauczyciel zyskuje możliwość kształtowania osądu profesjonalnego, w którym oprócz wiedzy teoretycznej wykorzystuje w działaniu opinie, intuicję pedagogiczną i mądrość wynikająca z dotychczasowej praktyki (Gasik 2010). Posługiwanie się analizą zdarzeń krytycznych może stanowić dla 
pedagoga swoisty trening kompetencji refleksyjnych. W przypadku kandydatów na nauczycieli możliwość tego rodzaju treningu dają praktyki zawodowe.

W wielu publikacjach pedagogicznych (m.in. Kosakowski 2003; Nowicka 2006; Frejman, Frejman 2008; Musiał 2013) podkreśla się szczególną rangę praktyk pedagogicznych jako tego elementu systemu kształcenia przyszłych nauczycieli, który rozwija refleksyjny stosunek do problemów związanych z organizacją nauczania, zwiększa zdolność samodzielnego kierowania własnym działaniem i dokonywania jego oceny, uczy wewnętrznej dyscypliny i odpowiedzialności za podjęte zadania. Kluczową kwestią staje się tu właściwa organizacja i nadzór nad przebiegiem praktyki oraz odpowiednie przygotowanie studenta do jej realizacji, gdyż - jak wskazują badania amerykańskie - studenci uczący się zawodu nauczycielskiego często działają podczas praktyk bezrefleksyjnie, korzystając wyłącznie z wiadomości zdobytych podczas studiów oraz odwołując się do poznanych przypadków (Woronowicz 2006).

Rola refleksji w praktyce pedagogicznej analizowana była przez wielu autorów. Powszechne uznanie, zarówno w pedeutologii, jak i nauce o wychowaniu i dydaktyce, zyskała koncepcja „refleksyjnego praktyka” Donalda Schöna. W koncepcji tej wyróżnia się dwa rodzaje refleksji: refleksję w działaniu (reflection in action) i refleksję nad działaniem (reflection-on-action) (Słaba 2014). Uruchomienie świadomego i pogłębionego namysłu przed działaniem, a potem w trakcie i po jego zakończeniu sprawia, że staje się ono swoistym eksperymentem, który pozwala na nowe rozumienie danej kwestii czy zjawiska (Perkowska-Klejman 2013). Nauczyciel w sposób twórczy wykorzystuje swoją praktykę - uczy się przez własne działanie, obserwację zachowań uczniów, poznawanie własnych i cudzych odczuć, opinii, poglądów; w ten sposób tworzy osobistą, indywidualną wiedzę wynikającą z doświadczenia, intuicji, często nieświadomego przetwarzania informacji gromadzonych podczas rozwiązywania problemu (Niemierko 2007). Refleksja w takim ujęciu nie oznacza, więc zastosowania teoretycznej wiedzy naukowej w praktyce. Wynika ona z praktycznego działania i pozostaje z nim w ścisłym związku, opiera się na umiejętności eksploracyjnego badania własnej aktywności zawodowej oraz przyjęcia postawy krytycznej autorefleksji osobistej i społecznej. Analizując swoje funkcjonowanie $\mathrm{w}$ roli zawodowej, refleksyjny praktyk koncentruje się na strukturze własnych przekonań wyznaczających jego sposób myślenia i zachowania. Bada i doskonali warsztat pracy, rozpatrując związki zachodzące między przyjmowanymi założeniami a osiąganymi rezultatami. Zdaniem Ewy Musiał (2013, s. 437):

rezultatem refleksji na poziomie teoretycznym powinno być konkretyzowanie struktury działań praktycznych nauczyciela-pedagoga oraz krytycyzm wobec własnej wiedzy i jej założeń realizowanych w trakcie działania. Ten swoisty krytycyzm ułatwia nauczycielowi tworzenie nowych wartości poznawczych. 
Mimo że refleksyjność uznawana jest obecnie za podstawę kompetencji zawodowych nauczyciela, badania krajowe prowadzone wśród studentów kierunków nauczycielskich wskazują na stosunkowo niską pozycję tej właściwości we wzorze osobowym pedagoga. Wśród cech charakteryzujących nauczyciela będącego dla ucznia autorytetem refleksyjność respondenci ocenili najniżej. Podobnie najmniejszą liczbę wskazań uzyskała ta właściwość w wykazie cech typowych dla nauczyciela-mistrza (Minczanowska, Hruzd-Matuszczyk 2013). Wyniki tych badań korespondują z jakościową analizą prac studentów pedagogiki, którzy wymieniając wymogi, jakie musi spełnić kandydat na pedagoga, stosunkowo rzadko odnosili się do kompetencji refleksyjnych (Śliwerski 2010).

\section{REFLEKSYJNOŚĆ W PRACY TYFLOPEDAGOGA}

Potrzeba systematycznego i krytycznego namysłu nad własnym myśleniem, wiedzą, poglądami, wartościami, a także nad działaniem (planowanym, realizowanym, dokonanym) wydaje się być szczególnie ważna w pracy pedagogów specjalnych. Niepełnosprawność, w zależności od jej rodzaju i stopnia, generuje szereg specjalnych potrzeb edukacyjnych, których zaspokojenie wymaga zmiany schematycznych, rutynowych rozwiązań dydaktyczno-wychowawczych, częstszych innowacji i wypracowania nowych metod nauczania-uczenia się (Skrzetuska 2012). Wprowadzenie skutecznych form oddziaływań dydaktycznych i rehabilitacyjnych nie jest możliwe bez pogłębionej refleksji i elastyczności działania, stąd w wykazie cech charakteryzujących sylwetkę pedagoga specjalnego Małgorzata Sekułowicz (2005) na pierwszym miejscu umieszcza właśnie refleksyjność i plastyczność myślenia. Zdaniem tej autorki powyższe właściwości są determinantami twórczego nauczania, terapii i opieki, gdyż pozwalają pedagogowi na identyfikację i eliminację błędów oraz zwiększają jego otwartość na zmiany, co skutkuje lepszym doborem form oddziaływań rehabilitacyjnych. Stanowisko to podziela Ewa Bartuś (2014, s. 208), która podkreśla, że:

każdy uczeń jest inny i niezależnie od stopnia swojej sprawności wymaga od nauczyciela głębokiej refleksyjnej postawy. Każdorazowo stanowi wyzwanie tym trudniejsze, im bardziej złożona jest jego sytuacja. Niepełnosprawność dziecka stwarza szereg nietypowych i niestandardowych sytuacji. Ważne jest, aby w każdym spotkaniu znajdować sens swoich działań. Im więcej nauczyciel zgromadzi w sobie potencjału, tym bardziej sprawnie, intencjonalnie będzie mógł wspierać i wspomagać ucznia, zwłaszcza tego ze specjalnymi potrzebami edukacyjnymi. 
Niepełnosprawność wzroku wiąże się z licznymi konsekwencjami fizyczno-zdrowotnymi, orientacyjno-poznawczymi i emocjonalno-społecznymi, które w znaczący sposób utrudniają realizację zadań szkolnych. Stopień i zakres tych trudności uzależniony jest od wielu wzajemnie powiązanych czynników osobistych i środowiskowych, wśród których poziom uszkodzenia wzroku nie odgrywa najistotniejszej roli. Nauczyciel, organizując proces kształcenia ucznia niewidomego lub słabowidzącego, musi stale przyjmować perspektywę indywidualną, czyli uwzględniać nie tylko powszechne następstwa dysfunkcji wzroku, ale także szereg innych, dynamicznych zmiennych (m.in. poziom motywacji do wykorzystywania $\mathrm{w}$ nauce osłabionego widzenia, biegłość $\mathrm{w}$ posługiwaniu się pomocami tyfloinformatycznymi, osobiste preferencje i doświadczenie w stosowaniu określonego rodzaju środków dydaktycznych itp.), które określają aktualne możliwości i potrzeby danego ucznia. Prawidłowa organizacja oddziaływań edukacyjno-rehabilitacyjnych wymaga, więc od nauczyciela zarówno teoretycznej wiedzy naukowej i praktycznych umiejętności z obszaru tyflodydaktyki, rehabilitacji wzroku, orientacji przestrzennej i bezpiecznego, samodzielnego poruszania się, jak i umiejętności pozyskiwania informacji z bezpośredniego działania tyflopedagogicznego i dotychczasowych doświadczeń zawodowych.

Stopień heterogeniczności potrzeb edukacyjnych w grupie uczniów z niepełnosprawnością wzroku, zwłaszcza uczniów słabowidzących, jest stosunkowo wysoki, stąd konieczność indywidualizowania stosowanych strategii dydaktycznych. Wiele problemów napotykanych w kształceniu uczniów z tym typem dysfunkcji ma charakter unikatowy, wielopłaszczyznowy, a ich rozwiązania są niejednoznaczne, zależne często od aktualnego kontekstu; zastosowanie w takich sytuacjach rutynowych technik mających postać gotowych procedur postępowania okazuje się na ogół nieskuteczne. Tyflopedagodzy unikają więc instrumentalnego podejścia do rozwiązywania problemów, starają się wypracowywać nowe strategie działania, bazując przy tym na wiedzy, doświadczeniu, intuicji, opiniach własnych i innych osób (w tym również samego ucznia), obserwacji, interpretacji danych ujawniających się już w trakcie podjętej aktywności. Refleksyjny namysł stale towarzyszy czynnościom tyflopedagogicznym, gdyż nietypowa strategia dydaktyczno-rehabilitacyjna, która przyniosła pożądany efekt w danej sytuacji, może w innych okolicznościach (np. po zmianie warunków otoczenia fizycznego) być już nieskuteczna.

Refleksyjność tyflopedagoga odgrywa ważną rolę zarówno na etapie diagnozy specjalnych potrzeb edukacyjnych ucznia z niepełnosprawnością wzroku, jak i w trakcie planowania, realizacji i ewaluacji zajęć dydaktycznych. We współczesnej tyflodydaktyce rekomendowana jest diagnostyka o charakterze funkcjonalnym, ukierunkowana na pozyskiwanie z różnych źródeł informacji o sposobie funkcjonowania ucznia w określonych warunkach szkolnych. Gromadzone dane pozwalają 
ocenić, w jakim stopniu, w jaki sposób i w jakich warunkach (m.in. chodzi o właściwości otoczenia fizycznego, adaptację materiałów szkolnych, zastosowanie pomocy rehabilitacyjnych) uczeń wykorzystuje wzrok. Materiał diagnostyczny wskazuje na potencjał dziecka, jego uzdolnienia, umiejętności, zainteresowania, a także ujawnia wynikające ze słabowzroczności lub niewidzenia problemy w różnych sferach codziennego funkcjonowania takich, jak np.: techniki uczenia się, odbiór informacji z otoczenia, orientacja w przestrzeni i przemieszczanie się, czynności życia codziennego itp. Lea Hyvärinen (2001, za: Walthes 2007) proponuje klasyfikację funkcjonalną, w której uwzględnia się rodzaj techniki wykonywania danej czynności w takich sferach codziennego funkcjonowania, jak: komunikacja, orientacja przestrzenna i poruszanie się, czynności dnia powszedniego, czynności wymagające precyzji. Przyjęta przez autorkę typologia opiera się na kryterium wykorzystywania wzroku w działaniu i obejmuje:

- techniki wzrokowe - standardowy sposób działania, typowy dla osób pełnosprawnych wzrokowo;

- techniki wzrokowe z zastosowaniem pomocy wspomagających osłabiony wzrok, charakterystyczne dla osób słabowidzących;

- techniki bezwzrokowe - oparte na dotyku i słuchu, wzrok nie jest stosowany do planowania, realizacji i kontroli czynności.

Identyfikując rodzaj zastosowanej techniki, należy każdorazowo wziąć pod uwagę wszelkie zmienne środowiskowe, które mogą mieć znaczący wpływ na wybór sposobu realizacji zadania (m.in. warunki atmosferyczne, oświetlenie, kolorystyka, kontrast, wielkość i struktura obiektów i wykorzystywanych przyborów, organizacja przestrzeni w pomieszczeniu i na stanowisku pracy itp.). Informacje zebrane w wyniku tego typu analizy odznaczają się wysoką użytecznością praktyczną, wskazują bowiem bezpośrednio na konkretny zakres i rodzaj wsparcia, jakiego dany uczeń potrzebuje w określonych okolicznościach. Ten sposób diagnozy zapobiega również etykietowaniu i rutynowemu stosowaniu oddziaływań terapeutycznych zwyczajowo przypisanych określonej dysfunkcji. Na przykład diagnoza może wykazać, że uczeń z niepełnosprawnością wzroku w świetle dziennym w znanym otoczeniu orientuje się w przestrzeni i porusza się, korzystając dominująco z posiadanych możliwości wzrokowych, zaś o zmroku, zwłaszcza w przestrzeni nieznanej, musi posłużyć się alternatywnymi technikami bezwzrokowymi charakterystycznymi dla osób całkowicie niewidomych (Walthes 2007). Diagnostyka funkcjonalna uznawana obecnie za optymalną w pracy z uczniami niewidomymi i słabowidzącymi wymaga znacznego zaangażowania ze strony nauczyciela, gdyż opiera się przede wszystkim na analizie materiału obserwacyjnego. Tyflopedagog musi wnikliwie obserwować zachowanie dziecka w różnych sytuacjach szkolnych, dostrzegać powiązania zachodzące między zmiennymi warunkami zewnętrznymi 
a sposobami i skutecznością radzenia sobie podopiecznego z zadaniami, świadomie modyfikować wybrane elementy organizacji procesu dydaktycznego i na bieżąco oceniać efektywność wprowadzanych rozwiązań. Podobne zadania stawiają przed nauczycielem założenia tzw. diagnostyki inkluzyjnej.

Sytuacja rozwojowo-edukacyjna ucznia z niepełnosprawnością wzroku ujmowana jest w diagnozie inkluzyjnej w sposób systemowy. Czynności diagnostyczne, uwzględniające szerokie spektrum zasobów osobowych i środowiskowych, koncentrują się na poznaniu i opisie opanowanych i znajdujących się w tzw. strefie najbliższego rozwoju umiejętności oraz zidentyfikowaniu najbardziej skutecznych strategii kompensujących u ucznia braki sensoryczne. Tyflopedagog za pomocą stałego dialogu z uczniem i innymi nauczycielami próbuje odnaleźć w środowisku szkolnym źródła trudności i zaproponować optymalne sposoby pokonania tych barier; propozycje te - odnoszące się m.in. do adaptacji przestrzeni fizycznej, dostosowania pomocy dydaktycznych, zastosowania odmiennych od dotychczasowych metod i form nauczania itp. - przyjmują formę hipotez, które weryfikowane są w działaniu (Czerwińska 2015). Diagnoza ściśle wiąże się więc z oddziaływaniami edukacyjno-rehabilitacyjnymi i ma charakter ciągły. Nie prowadzi do zakwalifikowania ucznia do pewnej kategorii, lecz stanowi elastyczną interpretację konkretnych zdarzeń i czynności szkolnych zachodzących w określonym kontekście. Wielość i zmienność czynników warunkujących sytuację szkolną ucznia z niepełnosprawnością wzroku sprawia, że w tego rodzaju diagnozie rzadko w pełni skuteczne okazują się znane techniki postępowania ujęte $\mathrm{w}$ formie gotowych procedur. Tyflopedagog niejednokrotnie odczuwa niepewność, podejmuje trud eksperymentowania, testowania, badania, a jego działaniom towarzyszy refleksja. Należy przy tym podkreślić, że refleksyjna i krytyczna postawa wobec założeń realizowanych w tych działaniach jest zależna od odpowiedniego poziomu kompetencji zawodowych.

Refleksyjne badanie własnej praktyki przez tyflopedagoga powinno dotyczyć wszystkich etapów procesu dydaktycznego. W trakcie planowania i realizacji zajęć nauczyciel winien stale pamiętać o odmienności percepcyjnej uczniów i dążyć do zminimalizowania negatywnych następstw uszkodzenia wzroku przez zastosowanie właściwie dobranych metod i pomocy szkolnych. Jak wskazują relacje z praktyki szkolnej (Dłuska i in. 2011), w nauczaniu uczniów z niepełnosprawnością wzroku często zachodzi konieczność odejścia od standardowych rozwiązań dydaktycznych na rzecz zindywidualizowanych strategii edukacyjnych. Poza pomysłowością i elastycznością, które w połączeniu z rzetelną wiedzą tyflopedagogiczną i umiejętnościami wynikającymi z doświadczenia praktycznego pozwalają nauczycielowi na wprowadzanie rozmaitych innowacji, istotną rolę odgrywa jego otwartość i szczególna wrażliwość na specyfikę zapoznawania się z rzeczywistością materialno-przyrodniczą, techniczną i kulturowo-społeczną w sytuacji niewidzenia 
lub słabowzroczności (Walthes 2014). Planując zajęcia, nauczyciel musi przewidywać, z jakimi zagadnieniami uczniowie z dysfunkcją wzroku mogą mieć trudności, i projektować określone działania pozwalające na kompensację braków sensorycznych. Aby zweryfikować przyjęte założenia, a także wyłonić nierozpoznane na etapie planowania problemy powodowane przez uszkodzenie wzroku, tyflopedagog w trakcie realizacji zajęć uważnie obserwuje zachowania uczniów, ocenia rezultaty ich pracy, modyfikuje swoje propozycje. Szczególnie istotna wydaje się analiza zachowań werbalnych uczniów, gdyż przez nie nauczyciel może najpełniej zapoznać się ze specyfiką bezwzrokowego pozyskiwania i przetwarzania informacji oraz ich łączenia z wcześniej przyswojonymi wiadomościami. Zadaniem tyflopedagoga jest wspieranie uczniów w zdobywaniu i integrowaniu danych. Powinien on wskazywać podopiecznym sposoby konstruowania znaczenia, organizowania zawartości, integrowania wiedzy uprzedniej z nowymi informacjami, odkrywania relacji między konkretem a uogólnieniem, stosowania ogólnych teorii i zasad w interpretowaniu zjawisk, wykorzystywania wiedzy w praktyce. W zrozumieniu pewnej odmienności funkcjonowania poznawczego uczniów niewidomych i słabowidzących niezbędne jest stałe bycie w dialogu, gdyż:

- uczniowie w trakcie wykonywania rozmaitych zadań (np. prowadzenia obserwacji, korzystania z pomocy przestrzennych i graficznych, manipulowania przedmiotami, udziału w zabawie dydaktycznej itp.) zadają pytania, które wskazują nauczycielowi na pewne luki czy nieprawidłowości w przyswojonej wiedzy (Jaworska-Biskup 2010; Więckowska 2011);

- nauczyciel zadaje pytania dotyczące przyszłej czy aktualnej aktywności uczniów, które ukierunkowane są m.in. na pobudzenie ciekawości poznawczej i skierowanie uwagi na te zjawiska, obiekty i relacje, z percepcją których dziecko ma obiektywne problemy, sprawdzenie rozumienia przez rozpoznanie trudności i skorygowanie błędów.

Prowadząc dialog, tyflopedagog przekazuje uczniom szereg informacji, które uzupełniają i rozwijają ich wiedzę o poznawanych zagadnieniach. W redagowaniu komentarzy, opisów i objaśnień kluczową kwestią jest refleksyjny namysł nauczyciela nad wykonywaną czynnością. Tyflopedagog musi w opisie w sposób logiczny, wewnętrznie spójny, uporządkowany zgromadzić najistotniejsze dane o omawianym obiekcie/zjawisku i przedstawić je za pomocą zrozumiałego języka, odwołując się do dotychczasowych doświadczeń ucznia. Wykonanie tego zadania jest pewnym wyzwaniem, wymaga dobrego rozumienia następstw niepełnosprawności wzroku i wrażliwości w przyjmowaniu perspektywy osoby z dysfunkcją wzroku. Nauczyciel może odwoływać się do pewnych ogólnych zasad z obszaru tyflodydaktyki, jednak nie dysponuje sztywną procedurą postępowania. Inną ważną kwestią, która jednoznacznie wskazuje na wagę refleksyjności w nauczaniu uczniów 
z niepełnosprawnością wzroku, jest potrzeba wyraźnego oddzielania w komentarzach objaśniających warstwy opisowej od interpretacji. Tyflopedagog powinien stale zadawać sobie pytanie, czy w dokonywanych opisach prezentuje możliwie jak najbardziej obiektywny stan rzeczy w celu skompensowania u uczniów braków danych, czy też opisy te stanowią jego własną, czasami bardzo mocno spersonalizowaną interpretację poznawczo-emocjonalną określonego obiektu czy zjawiska, m.in. dzieł sztuki (malarstwo, grafika, fotografia, film). Na przykład na zajęciach z rehabilitacji podstawowej przy omawianiu zasad doboru ubioru należy zapoznać uczniów z określonym kanonem obowiązującym w danym kręgu kulturowym, nie zaś przedstawiać osobiste preferencje w tym zakresie jako ogólnie przyjęte czy też optymalne. Przekazując określone treści, tyflopedagog powinien być świadomy ich ideologicznych i światopoglądowych znaczeń.

\section{PODSUMOWANIE}

Praca z uczniem z niepełnosprawnością wiąże się z silnym poczuciem odpowiedzialności za działania podejmowane w procesie wspierania jego rozwoju, $\mathrm{w}$ tym przygotowania go do sprawnego funkcjonowania w zmieniającej się rzeczywistości społeczno-kulturowej. Nauczyciel podejmujący się tego zadania zobowiązany jest do ustawicznego uczenia się, ukierunkowanego zarówno na doskonalenie i nabywanie nowych umiejętności instrumentalnych, jak i na rozwijanie pożądanych cech osobowościowych (Bartuś 2014). Zdolność do refleksji jest jedną z tych właściwości, które stanowią podstawę efektywnej aktywności zawodowej nauczyciela uczniów z niepełnosprawnością. Dzięki tej cesze pedagog specjalny wnikliwie i systematycznie poznaje swój warsztat pracy, co pozwala mu na doskonalenie podejmowanych działań, korygowanie błędów i zapobieganie im. Refleksyjność uwrażliwia pedagoga na szczególne potrzeby ucznia z niepełnosprawnością i uruchamia jego twórczy potencjał w zakresie poszukiwania niestandardowych metod pracy.

Badania nad wypaleniem zawodowym pedagogów specjalnych przeprowadzone przez Małgorzatę Sekułowicz (2005) wśród nauczycieli pracujących z osobami z niepełnosprawnością intelektualną dowiodły, że refleksyjne nauczanie jest $\mathrm{w}$ wielu przypadkach nadal tylko teoretycznym postulatem. Badani pedagodzy w małym stopniu wykorzystywali posiadaną wiedzę jako źródło zawodowej refleksji, co badaczka łączy przede wszystkim z brakiem predyspozycji osobowościowych oraz wadliwym systemem akademickiego kształcenia, który nie sprzyja nabywaniu kompetencji do refleksyjnego namysłu. Podobne eksploracje badawcze nie były podejmowane w kraju w grupie nauczycieli i terapeutów pracujących z uczniami niewidomymi i słabowidzącymi. Niewątpliwie badania takie miałyby znaczną wartość poznawczą i aplikacyjną. 


\section{LITERATURA}

Bartuś E., 2014, Integralna działalność nauczyciela w pracy z uczniem ze specjalnymi potrzebami edukacyjnymi. W: J. Wyczesany (red.), Dydaktyka specjalna. Wybrane zagadnienia. Gdańsk, Harmonia Universalis.

Chudy W., 2006, Refleksja. W: E. Różycka (red.), Encyklopedia Pedagogiczna XXI wieku, t. 5. Warszawa, Wydawnictwo Akademickie Żak.

Czaja-Chudyba I., 2008, Przygotowanie nauczyciela do rozwijania myślenia krytycznego u dzieci. W: B. Muchacka, M. Szymański (red.), Nauczyciel w świecie. Kraków, Oficyna Wydawnicza Impuls.

Czaja-Chudyba I., 2013, Myślenie krytyczne w kontekstach edukacji wczesnoszkolnej - uwarunkowania nieobecności. Kraków, Wydawnictwo Naukowe Uniwersytetu Pedagogicznego.

Czerwińska K., 2015, Edukacja inkluzyjna uczniów z niepełnosprawnością wzroku. W: S. Sobczak L. Pytka, T. Zacharuk (red.), Edukacja inkluzyjna. Teoria - system metoda, cz. 1, Siedlce, Uniwersytet Przyrodniczo-Humanistyczny w Siedlcach.

Dłuska J., Karwowska M., Karasińska W., 2011, Świat w zasięgu ręki. Dobre praktyki w edukacji uczniów z dysfunkcja wzroku - projekt „Bliżej świata - od konkretu do abstrakcji”. Bydgoszcz, Specjalny Ośrodek Szklono-Wychowawczy dla Dzieci i Młodzieży Słabo Widzącej i Niewidomej.

Frejman M., Frejman S.D., 2008, O rozwijaniu refleksyjnej postawy przyszłych nauczycieli. W: B. Muchacka, M. Szymański (red.), Nauczyciel w świecie współczesnym. Kraków, Oficyna Wydawnicza Impuls.

Gasik J., 2010, Pedagog specjalny w kształceniu uczniów ze specjalnymi potrzebami edukacyjnymi. W: J. Głodkowska (red.), Dydaktyka specjalna w przygotowaniu do kształcenia uczniów ze specjalnymi potrzebami edukacyjnymi. Warszawa, Wydawnictwo Akademii Pedagogiki Specjalnej.

Hejnicka-Bezwińska T., 2008, Pedagogika ogólna. Warszawa, Wydawnictwa Akademickie i Profesjonalne.

Jaworska-Biskup K., 2010, Dlaczego warto uczyć dzieci niewidome języków obcych? Języ obcy jako kompensacyjne narzędzie w procesie poznawania świata i zdobywania wiedzy na temat pojęć. W: T. Żółkowska, B. Ostapiuk, M. Wlazło (red.), Wyzwania współczesnej pedagogiki specjalnej - praktyka edukacyjna i rewalidacyjna. Szczecin, Uniwersytet Szczeciński.

Kojs W., 2012, Edukacja i pedagogika w społeczeństwie wiedzy - wybrane zagadnienia. „Chowanna”, 2(39), 21-37.

Kosakowski Cz., 2003, Węzłowe problemy pedagogiki specjalnej. Toruń, Wydawnictwo Edukacyjne Akapit. 
Minczanowska A., Hruzd-Matuszczyk A., 2013, Ksztaltowanie kompetencji pedagogicznych przyszłych nauczycieli poprzez realizacje praktyk zawodowych. W: E. Musiał, M. Bednarska (red.), Współczesna przestrzeń edukacyjna. Geneza, przemiany, nowe znaczenia, t. 2. Kraków, Oficyna Wydawnicza Impuls.

Musiał E., 2013, Wyznaczniki profesjonalizmu nauczycieli w przestrzeni edukacyjnej. W: E. Musiał, M. Bednarska (red.), Współczesna przestrzeń edukacyjna. Geneza, przemiany, nowe znaczenia, t. 2. Kraków, Oficyna Wydawnicza Impuls.

Niemierko B., 2007, Kształcenie szkolne. Podręcznik skutecznej dydaktyki. Warszawa, Wydawnictwa Akademickie i Profesjonalne.

Nowicka M., 2006, Kopiuj, a nie wymyślaj - rzecz o praktycznym przygotowaniu do zawodu nauczycielskiego. W: M. Suświłło (red.), Zaniedbane i zaniechane obszary edukacji w szkole. Olsztyn, Wydawnictwo Uniwersytetu Warmińsko-Mazurskiego.

Paris S.G., Ayres L.R., 1997, Stawanie się refleksyjnym uczniem i nauczycielem. Warszawa, Wydawnictwa Szkolne i Pedagogiczne.

Perkowska-Klejman A., 2013, Refleksyjność w praktyce edukacyjnej. W: W. Żłobicki (red.), Współczesna przestrzeń edukacyjna. Geneza, przemiany, nowe znaczenia, t. 1. Kraków, Oficyna Wydawnicza Impuls.

Rynio A., 2009, Dojrzałość nauczycieli warunkiem twórczego rozwoju i przetrwania cywilizacji. W: B. Zawadzka (red.), Szkoła w perspektywie XXI wieku. Teraźniejszość - Przyszłość, cz. 3. Kielce, Wydawnictwo Uniwersytetu Humanistyczno-Przyrodniczego Jana Kochanowskiego.

Sekułowicz M., 2005, Nauczyciele szkolnictwa specjalnego wobec zagrożenia wypaleniem zawodowym. Analiza przypadków. Wrocław, Wydawnictwo Naukowe Dolnośląskiej Szkoły Wyższej Edukacji TWP.

Skrzetuska E., 2012, Dylematy koncepcji neonowoczesnej szkoły a niepetnosprawność ucznia. W: Z. Palak, D. Chimicz, A. Pawlak (red.), Wielość obszarów we współczesnej pedagogice specjalnej. Lublin, Wydawnictwo Uniwersytetu Marii Curie-Skłodowskiej.

Słaba D., 2014, Wokół zagadnień refleksyjności w rozwoju człowieka dorosłego. „Chowanna", 2(43), 321-338.

Śliwerski B., 2010, Myśleć jak pedagog. Sopot, Gdańskie Wydawnictwo Psychologiczne.

Walthes R., 2007, Tyflopedagogika. Gdańsk, Gdańskie Wydawnictwo Psychologiczne.

Walthes R., 2014, Einführung in die Pädagogik bei Blindheit und Sehbeeinträchtigung. München, Reinhardt Verlag.

Więckowska E., 2011, Edukacja nie wystarczy - potrzeby rewalidacyjne dziecka niewidomego w wieku szkolnym. W: B. Antoszewska, Cz. Kosakowski (red.), 
Uwarunkowania i kierunki rozwoju pedagogiki specjalnej. Toruń, Wydawnictwo Adam Marszałek.

Woronowicz W., 2006, Refleksyjny praktyk. W: E. Różycka (red.), Encyklopedia Pedagogiczna XXI wieku, t. 5. Warszawa, Wydawnictwo Akademickie Żak.

\title{
REFLEXIVE APPROACH IN TEACHING STUDENTS WITH VISUAL IMPAIRMENT - SELECTED THEORETICAL ISSUES
}

\begin{abstract}
In a model profile of a special education teacher described in pedeutological literature, the reflexive approach holds the leading position - next to skills and abilities based on theoretical and methodological knowledge. The ability to be critical about one's own thinking and performance is particularly important in teaching of students who represent different mode of perception. Reflexive approach makes the teacher more open and sensitive to specific styles of learning about the material, natural, cultural and social reality by that group of students. Such an approach contributes to avoiding inappropriate pedagogical practices. The effectiveness of the teacher of the visually impaired (TVI) is not determined solely by the ability to apply theoretical knowledge in practice but also by the ability to reflect on the currently implemented and the completed activities. Reflexive approach of the teacher to his/her own performance is as important in the phase of diagnosing special educational needs of the student with visual impairment as in the phase of planning, implementing and evaluating didactic activities. The TVI has to collect observations from various school situations and analyse dynamic interactions between the learning environment he/she designs and the current abilities and needs of a specific student with visual impairment. The TVI should be open to frequent changes occurring in the analysed area.
\end{abstract}

Key words: reflexive approach, teacher, teacher of the visually impaired, visual impairment 